\title{
Collision of Identities. Assimilation and Myth-making among Hungary's Greek Catholics. By Bertalan Pusztai.
}

Bucharest: Editura Universitară, 2019. 391 pp.

\section{Eszter Győrfy}

Institute of Ethnology, Research Centre for the Humanities, ELKH, H-1097 Budapest, Tóth Kálmán u. 4, Hungary; gyorfy.eszter@abtk.hu

The Greek Catholic churches of East Central Europe were established between the sixteenth and eighteenth centuries in the political buffer zone of the eastern and western part of Europe where different ethnic groups have coexisted ever since. They were characterized by an ambiguous position between Eastern and Western Christianity, but they also formed a bridge between two political and cultural spheres. The ethnic character of the denomination was very important: originally, Greek Catholics were Rusyns, Ukrainians, and Romanians and religious and ethnic affiliations were closely intertwined in their lives. The autonomous Greek Catholic churches played a central role in the increasing political activity and nation-building processes of these minorities in the nineteenth century. These churches were greatly influenced by political processes and transformations: the border changes after World War I and the decades of prohibition after World War II were significant turning points for their communities. More recently, the Eastern European regime changes have created the opportunity for their re-emergence and re-organization.

In the past 30 years, Greek Catholic churches-their history and their communities-have aroused increasing interest among scholars, especially (church) historians and anthropologists. Bertalan Pusztai from the University of Szeged has studied a less well-known group, Hungarian Greek Catholics, for decades. He conducted ethnographic fieldwork in some (former and present-day) Hungarian Greek Catholic communities of Subcarpathian Ukraine and Transylvania, and did extensive historical research on the nineteenth and twentieth century assimilation and identity-building processes of Hungarian Greek Catholics.

Hungarian-speaking Greek Catholics lived in a multiple-minority situation in the northeastern part of the Kingdom of Hungary and in Transylvania: they were a linguistic minority group within a minority church. They were the descendants of Rusyn and Romanian Greek Catholics who went through a long process 
of assimilation during the eighteenth and nineteenth centuries and wanted to both identify with the Hungarian nation and emphasize their separation from other nationalities. Still, their ethnically intermediary position-their Rusyn and Romanian ethnic origins, Hungarian language and identity-created a climate of suspicion around them.

The present volume "seeks to give an overview of the identity-shaping discursive processes and strategies of Hungarian Greek Catholics triggered by their assimilation" (p. 8). Following the first introductory chapter (The Hungarian Greek Catholics: Identity and Historical Consciousness) the book contains the slightly or considerably modified English versions of the author's seven, previously published (English and Hungarian) studies on the topic.

The second chapter, Assimilation on the Hungarian Greek Catholic Periphery, examines the ethnic and religious changes in a Subcarpathian village from the eighteenth to the twentieth century, focusing on the linguistic assimilation process of the local Rusyn community.

The next chapter, Discursive Tactics and Identity Search at the Fin de Siècle, analyzes the so-called Memorial Album published in honor of the pilgrimage of a group of Hungarian Greek Catholics to Rome in 1900. The author discusses the visual symbolism and the discursive layers of the album and considers it to be a symbolic representation of the Hungarian Greek Catholic community and an important step in the creation of a unique historical consciousness that formed the basis of a new Hungarian Greek Catholic identity.

Discoursing Boundaries: Identity Creation in the Interwar Period elaborates further on the creation of this historical consciousness and the attempts of the Greek Catholic elite to position this group in the social space of the time; that is, the seriously traumatized Hungarian society of the interwar period. The chapter is based on the analysis of the Greek Catholic press and gives an overview of the "invention" of this group's history that was an important part of the process of their integration.

Chapter 5, A Religious Diaspora Community in the Interwar Years, presents the history of a Greek Catholic community that was formed outside the "main" Greek Catholic areas of northeastern Hungary. The author focuses on the most intensive years of community building and formation between 1921 and 1936 and shows the most important factors in the empowerment of this local religious group.

The Fate of Hungarian Greek Catholics in $20^{\text {th }}$ century Szeklerland, Romania is an essay based on archival documents and interviews but written in the name of a fictive Greek Catholic priest of a Transylvanian village. It introduces the reader to the twentieth-century assimilation processes and political changes of the region and the fate of the rather small local Greek Catholic communities. 
The next chapter, Institutional Changes in the Greek Catholic Church in Hungary, 1950-2000, summarizes the history of the Greek Catholic Church in Hungary and its institutions, focusing on the second half of the twentieth century and especially the post-socialist period.

The last chapter, Paths to Identification in a Double Minority, is based on fieldwork in three Subcarpathian villages. The author examines the different identification strategies of former Hungarian Greek Catholics in the socialist era and the confessional conflicts that arose from "collisions of identity" (p. 186) within these communities after the regime change and the revitalization of Greek Catholicism, in parallel with more general sociopolitical transformations.

The Appendix of the book (pp. 215-391) contains the English translation of the Memorial Book of the Roman Pilgrimage of the Greek Catholic Hungarians.

The book comprises separate studies, each analyzing different "aspects of the social history of Hungarian Greek Catholicism" (p. 7) and they can be read individually. Despite the differences in the focus of the studies, they also complement one another and in the end the reader gets a general overview of the main topics and concepts of the study of Hungarian Greek Catholics and their eighteenth-twentieth-century history (although this structure leads to a fair amount of repetition as well). We get to know about assimilated, Hungarian-speaking communities of Rusyn and Romanian ethnic origin with a distinct religious identity. During the nineteenth and twentieth centuries the elite of these geographically and socially peripheral communities struggled for national and social integration and the survival of their religious identity and traditions at the same time. The author's historical overviews and ethnographic accounts also show that, in the case of Hungarian Greek Catholics, and depending on the circumstances, ethnic and religious identity can both support and contradict each other.

This collection of studies-complemented with the translation of an important historical source-will be of great interest to international researchers of Greek Catholicism and Greek Catholic Churches and also to scholars attentive to the questions of religious transmission and the questions of continuity and change in religious traditions and identity in general.

(c) 2021 The Author(s).

(c) (7) This is an open-access article distributed under the terms of the Creative Commons Attribution-Non Commercial 4.0 International Licence (CC BY-NC 4.0). 